\title{
Derridean Hauntology
}

\section{in Selected Poetry of Maya Angelou and Lucille Clifton Naglaa Saad M. Hassan, PhD*}

\author{
nsm01@ fayoum.edu.eg
}

\section{Abstract}

This paper deals with aspects of Derridean hauntology in the poetry of May Angelou and Lucille Clifton, two prominent, albeit understudied, African American women poets. Starting with an overview of Jacque Derrida's postulations disclosed in his book Specters of Marx, the study is then to situate his theory in selected poetry by the two poets aforementioned with the attempt of showing how it helps delve deeper into the nuances of African American consciousness. The paper argues that given the intensive studies on specters, legacies and memories, what distinguishes Derrida's theory is its tripartite link to temporality, existentialist being and hegemony. With Derrida asserting that specters control the present and the future and determine being and becoming besides governing the quest for hegemony, Derridean hauntology not only unsettles the taken-for-granted notions of temporality but also disrupts the conventional concepts of existentialist being and power. Bringing the three-aspected hauntology to Angelou and Clifton's poetry helps shed light on the role of textuality and the author in the struggle over hegemony and in the attempt to reconcile the conflicting poles of being in the case of black American subjects. To achieve its objectives, the study is to follow an expository analytic approach wedding theory to practice and foregrounding the poetic devices that help hammer forth the Derridean perspective.

Keywords : Jacques Derrida, hauntology, Maya Angelou, Lucille Clifton, specters, hegemony, textuality, Being.

\footnotetext{
* Associate Professor, English Department Fayoum University
} 


\section{Derrida's Theory of Hauntology, an Overview}

In his book, Specters of Marx (1993), Jacques Derrida coins the term hauntology to refer to the atemporality of Marxism showing how its tenets are still haunting the political and cultural scene despite the death of its founder and the seeming failure of communism after the disintegration of the Soviet Union, the end of the Cold War and the fall of the Berlin Wall. Using Marx's very words ("A specter is haunting Europe- the specter of communism") disclosed in the 1848 "the Manifesto of the Communist Party" , Derrida asserts that at "a time when a new world disorder is attempting to install its neo-capitalism and neoliberalism, no disavowal has managed to rid itself of all of Marx' $\mathrm{s}$ ghosts"(45). Widening his critical scope, he argues that hauntology includes "all the forms of a certain haunting obsession that seems to... organize the dominant influence on discourse today" (45).

It is the argument of this paper that given the widereaching scholarship on ghosts and spectrality, Derrida's theory of hauntology would not have broken new grounds had it not been entangled with the politics of hegemony, being, and time. In the course of his discussion, Derrida shows how hauntology deconstructs the totalitarian autonomy of hegemony, the definiteness of temporality and the typical assets of being. Underlining the relationship between hauntology and hegemony, Derrida writes that "haunting belongs to the structure of every hegemony" (46). As his argument unfurls, it becomes clear that for him, spectrology involves two important acts: haunting, in which the ghost enjoys full authority upon the haunted subject, and conjuration in which agency is shared by both the conjurer and the specter. For Derrida, conjuration "is first of all an alliance, ... sometimes a political alliance.... It is a matter of neutralizing a hegemony or overturning some power" (58). He

\section{(Derridean Hauntology...) Dr. Naglaa Saad M. Hassan}


illustrates how in the Middle Ages, the word "conjuratio" was designated so that the "bourgeois joined together, sometimes against a prince to establish free towns" (59) and how in the occult society, "certain subjects, either individual or collective, represent forces and ally themselves together in the name of common interests to combat against a dreadful political adversary, that is, to conjure it away" (59; emphasis added). Conjured specters, therefore, have long been entangled with unsettling hegemonic forces with the ultimate aim of achieving justice. Such emphasis on justice as a propelling objective for Derrida's conceptualization of specters is straightforwardly put forward: "If I am getting ready to speak at length about ghosts , inheritance, and ... generations of ghosts, which is to say about certain others who are not present, nor presently living, either to us, in us, or outside us, it is in the name of justice (xviii).

As far as temporality and existentialist being are concerned Derrida sums up their interlocking relationship with hauntology when he explicitly asserts that "it is necessary to introduce haunting into the very construction of... every concept, beginning with the concepts of being and time. That is what we would be calling here a hauntology" (220; emphasis added). Throughout his book, the idea of spectral atemporality is steadily underlined. In his definition of haunting, Derrida contends that it is "historical ... but ... not dated. It is never docilely given a date in the chain of presents, day after day, according to the instituted order of a calendar" (3). Atemporality is also evident in the very terms he uses in reference to ghosts. Hence, a ghost is not a "phantom" but rather a "revenant" whose comings and goings cannot be controlled. " A ghost is repetition and a first time," he contends, "but also repetition and last time... Each time it is the event itself, a first time is a last time" (10). Situating his theory in literature, Derrida writes that "as in Hamlet ...everything begins by the 
apparition of a specter. ... more precisely, everything begins in the imminence of a re-apparition, but a re-apparition of the specter as apparition for the first time in the play" (2). The same goes for the specters in Macbeth and Julius Caesar: "Think as well of Macbeth , and remember the specter of Caesar", he writes, "After having expired, he returns. Brutus also says "again" (11).For Derrida, therefore, a ghost is "furtive and untimely" and "the apparition of the specter does not belong to that time, it does not give time" (xix). A haunting specter occupies a liminal space in temporality because even though it belongs to the past, it 'begins by coming back' (11). In this light, Derridean hauntology disrupts the fixed notions of time and linear historicity; if specters of the past are to re-visit us now and tomorrow, the idea of temporal finite ending is questionable. Derrida encapsulates such atemporality by citing Hamlet's words "the time is out of joint". History is never dead; its events, ideologies and figures lie beneath the surface threatening to manipulate the present and shape the future.

That hauntology is entangled with existentialist Being is further underlined in more than one point in his book. Tying haunting with inheritance and Being, Derrida contends that people are haunted by the specters of Marx because they are his inheritors: "one must assume the inheritance of Marxism... Inheritance is never a given, it is always a task...To be... means...to inherit. All the questions on the subject of Being or of what is to be (or not to be) are questions of inheritance"(67). At another point in his book, he tackles the relationship between hauntology and ontology- the field of philosophy concerned with Being and Becoming- arguing that hauntology is "larger and more powerful than an ontology or a thinking of Being (202). Simultaneously tying specters with Being and hegemony, Derrida argues that spectral visitation acts as an exorcising force 
threatening the seamless act of Becoming. Such exorcising effect requires performativity on the part of the haunted visitor; he is either totally unable to reconcile his corporeal self with the noncorporeal invisible specter and is hence subdued by the specter's hegemony, or is aided by such power in the act of self-definition and identity construction. Hauntology, therefore, creates an inbetween space between being and non-being, existence and nihilism, life and death, power and powerlessness with the ultimate end of tying one's being with the ever-returning specters.

Controversial $^{1}$ as it has been regarded, Derrida's theory has been adopted as an interdisciplinary approach in numerous fields including psychology, theology, anthropology, ethnography and philosophy. In fact, it is credited for the provenance of the socalled seminal concept of "the spectral turn" encapsulating the intensive studies on specters and haunting. With Derrida frequently citing extracts of Shakespearean texts, he has indeed situated his theory within literature, hence planting the seed for further scholarly investigations. Derridean spectrality- with its existentialist hegemony-oriented facets and its emphasis on the atemporality of legacies, memories and ideologies can yield highly assuming results in literary analysis. Central to such critical exploration, however, is the focus on a certain culture given that each has its own historical legacies and pertinent forms of spectrality, hence the focus on African American culture in the study at hand.

To achieve its objectives, this paper is to focus on the poetry of Lucille Clifton (1934-2010) and Maya Angelou (19282014), two prominent African American women poets whose oeuvre offer rich material for the three-aspected Derridean perspective. The importance of the study lies in bringing Derrida's theory to African American poetry ${ }^{2}$ on the one hand and in further illuminating Derrida's theory through his preferred lens

(Derridean Hauntology...) Dr. Naglaa Saad M. Hassan 
of literature, on the other. In tracing and analyzing the Derridean specters, materializing as images, themes and motifs in selected poems by the two poets, the study attempts to answer the following questions: what type of specters figuring out most prominently in their output and how far are they related to the existentialist dilemma of black people suffering under the yoke of white hegemony and atemporal re-visiting specters of racist oppression? What is the relationship between textuality, spectrality and hegemony?

\section{Maya Angelou, from Anonymous Specters to those of Fathers}

Maya Angelou, African American poet, memoirist, journalist and activist is particularly acclaimed for resisting antiblack oppression and empowering African American women. Despite the depth of poetic vision and the virtuosity of technical skills, Angelou's poetry has not been studied as much as her autobiographies. In the introduction to his edited book on Maya Angelou, Harold Bloom rightly contends that "her poetry has a large public, but very little critical esteem" (1). He claims, however, that it is , in every sense, "popular poetry," and makes no formal or cognitive demands upon the reader," (1) a view which the succeeding analysis is to methodically refute. Reading through Angelou's poetic oeuvre, one observes a recurrent materialization of Derridean atemporally visiting specters and their entanglement with the nuances of her poetic vision on the question of being, justice and power. Varying from anonymous to specific and from images to figures, Angelou's specters reflect an ever-questioning subject aiming to disrupt White hegemony, overcome multiple forms of oppression and resolve Black racismrelated existentialist dilemma.

(Derridean Hauntology...) Dr. Naglaa Saad M. Hassan 
Unidentified universal specters are met in her poem "Remembering" in which the poet captures in deftly-crafted images the state of haunting threatening the persona's Being:

Soft grey ghosts crawlup my sleeve

to peer into my eyes

while I within deny their threats

and answer them with lies.

Mushlike memories perform

a ritual on my lips

I lie in stolid hopelessness

and they lay my soul in strips (Collected Poems 14).

With Derrida asserting that "the specter is also, among other things, what one imagines, what one thinks one sees and which one projects - on an imaginary screen where there is nothing to see" (126) , Angelou's poem strikes a non-equivocal Derridean note. Derrida uses the term "frequentation" to refer to the frequent visits specters pay to targeted haunted subject, a fact technically enhanced by the use of the habitual present simple tense. Evidently, the specters assume hegemony over the persona, a fact stylistically mirrored by the dense use of dynamic verbs describing their actions (crawl, peer, perform, lay in strips") in comparison with recurrent stative verbs hammering home the persona's inertia. Spectral imminence is further accentuated by adeptly knitted visual and kinetic images; hence the image of "crawling and peering" which, besides suggesting the power of sight and mobility of the supposedly invisible lifeless ghosts, insinuates the inescapable threat historical legacy and memories exercise on the present. The absurdity of the situation is paralleled by the image of "mushlike memories" which perform rituals on the persona's lips, with "mushlike" belonging to the stock of domestic life, and "rituals" carrying sacred overtones. In this weird episode, however, the specter is indivisible from the persona, a fact stylistically pinpointed by the use of the deictic

\section{(Derridean Hauntology...) Dr. Naglaa Saad M. Hassan}


preposition "on" tying the two pertinent phrases together in an unending haunting relationship. The poem ends on a melancholic tone with the persona admitting her despair whilst the specter is tearing her soul into "strips". The existentialist Hamletian question of "to be or not to be" remains unresolved.

Whereas in the poem above, spectrality assumes anonymous unidentified form, in others there are distinct specters primary among whom are those of slavery which tends to haunt African American culture ${ }^{3}$ per se. In fact, slavery as a theme, an image and a motif has been at the center of African American poetry ever since its very birth at the hand of Phillis Wheatley towards the end of the eighteenth century. Elizabeth Ann Beaulieu rightly contends that " the reinvention of the slave narrative by black women writers in the late twentieth century constitutes the rebirth of the .. proudest tradition in African American literature (15). In addition to counterpoising the Western stereotypical discourses, re-inscribed slavery tales, in line with Derridean atemporal spectrality, keep "some stories from ending... [giving] writers ... a sense of beginning, even a new identity, by virtue of their anti-slavery activity" ( Sekora 31) . The heavy incidence of slavery specters can also be explained in terms of the incessant chain of racial hegemonic prejudices targeting black Americans even after the constitutional abolition of slavery in 1863. In Derridean terms, “conjuration is meant to conjure away... One must, magically, chase away a specter, exorcise the possible return of a power ... whose demonic threat continues to haunt'(120). Accordingly, African American writers' conjuration of slavery specters, which are symbolic of imperialistic tyranny, is a means of resistance, a tool whereby the author protests against white hegemony with its atemporal chain of oppressions.

(Derridean Hauntology...) Dr. Naglaa Saad M. Hassan 
In Angelou's poetry, slavery specters assume two forms which mostly entwine and overlap: visualized images of historical events, and figures of activists and ancestors. In each poem, such spectral formulations are entangled with the existentialist dilemma of the haunted Afro American subject on the one hand and the writer/conjurer's attempt to dismantle White hegemonic discourse on the other. Prominent among these poems is "Guilt" which, informed by its very title, lays bare the effect of spectral memories on the persona's Being:

My guilt is "slavery's chains," too long the clang of iron falls down the years. This brother's sold, this sister's gone, is bitter wax, lining my ears.

My guilt made music with the tears.

My crime is "heroes, dead and gone," dead Vesey, Turner, Gabriel, dead Malcolm, Marcus, Martin King. They fought too hard, they loved too well. My crime is I'm alive to tell (Collected Poems 45) .

The poet weds visualized images of "slavery chains" and selling scenes of "brother[s]" and "sister[s]" to a list of memorable "heroes" whose names are engraved in African American history. Starting with the early pre-abolition stage, Angelou textually conjures up the specters of early anti-slavery activists : Denmark Versey (1767-1822), Ned turner (1800-1831) and Gabriel Posser (1776 -1800) whose respective rebellions contributed to the historic end of bloody bondage. Moving linearly across historical records , Angelou brings out the heroes of the Civil Rights Movement and black Nationalist movements- Martin Luther King, Malcolm X and Marcus Garvey. Apart from celebrating the figures, the poet conjures them to highlight her own existentialist tension. It is worth noting here that in Derrida's perspective, spectrology is

\section{(Derridean Hauntology...) Dr. Naglaa Saad M. Hassan}


entangled with guilt and anxiety- two inherent existentialist feelings. In the course of his discussion, he declares that a ghost is the "guilty body" of a spirit, and that "conjuration ..... is never free from anxiety... The conjuration is anxiety from the moment it calls upon death to invent the quick and to enliven the new, to summon the presence of what is not yet there (noch nicht Dagewesenes)" (135 ). Unable to change the injustice of the present, the African American subject, beset with guilt regarding the haunting oppressive acts that inflicted his community and still overwhelmed with anxiety as to potential revenant oppressions, conjures the dead specters on the written text as a means of selfreconciliation between his corporeal self and the non-corporeal legacy. With the poet/ persona declaring "my crime is that I'm alive to tell", the role of textuality in handling such anxiety and destabilizing white hegemony through spectrology is nailed down. Not only are the spectral figures her own guilt, crime and sin, but they are also metaphorically imaged as "bitter wax" lining her ears, an image which points to the continuity of the existentialist inseparability of the persona and the specters. The swift transition from the authorial lyrical first-person voice in the first two stanzas to that of the speaking slave in the final lines further augments such unity:

My sin is "hanging from a tree,"

I do not scream, it makes me proud.

I take to dying like a man.

I do it to impress the crowd.

My sin lies in not screaming loud (Collected Poems 45)

The voice textually endowed to the slave is meant to assuage the guilt overwhelming the haunted poet/persona. Continuously silenced even at the time of his murder, the slave is now speaking out "loud" not to "impress the crowd", as he caustically declares, 
but to awaken global conscience. In contrast to the debased witless slave represented in Eurocentric discourse, the slave talks in selfappreciative censuring high-pitched tone using favorable positive lexis ("proud", "man") to inscribe his heroism. Much in line with Derrida's concept of the specter as revenant, his determinedly inexhaustible death is imaged in present simple tense; not only is his specter coming over and again, but the moment of his death is to be endlessly re-staged.

While in the previous poem we have encountered brothers, sisters and historic activists, in "Song for the Old Ones", we have reverend Fathers, atemporally returning in flesh and blood to sit, count and nod :

\author{
My Fathers sit on benches \\ their flesh counts every plank \\ the slats leave dents of darkness \\ deep in their withered flanks.
}

They nod like broken candles

all waxed and burnt profound

they say "It's understanding

that makes the world go round" (Collected Poems 108).

Still counterpoising the Western stereotype of the dim-witted slave/Negro, the fathers speak up in witty self-appreciative tone. Though psychically wounded, broken and "burnt profound", they are wise enough to teach us that sacrifice and understanding make "the world go round". In the succeeding lines, the narrative voice mingles with the lyrical I to present an intensive picture of spectral slavery episodes:

There in those pleated faces

I see the auction block

the chains and slavery's coffles

the whip and lash and stock (Collected Poems 108 ).

\title{
(Derridean Hauntology...) Dr. Naglaa Saad M. Hassan
}


Note how the image of the "pleated face", denoting the commonality of suffering, is followed by a series of harsh visual ones re-creating anew the unending haunting scenes of slavery. Hence, images of "auction blocks" , "coffles" as well as "whip"ping and "lash"ing with their mimetic onomatopoeic resounding effect. In the succeeding stanzas, the poet shifts again from the lyrical "I" to the third person narrative voice and from the present simple to the past tense with the overall effect of shifting hegemonic scales from the specters to the author who controls the re-staged re-presented scene:

They used the finest cunning

their naked wits and wiles

the lowly Uncle Tomming

and Aunt Jemimas' smiles.

They've laughed to shield their crying

then shuffled through their dreams

and stepped 'n' fetched a country

to write the blues with screams.

I understand their meaning

it could and did derive

from living on the edge of death

They kept my race alive (Collected Poems 108-109)

The image of "cunning", the "naked wits and wiles" along with the artistic music (blues) continues the scheme of resignification on stereotyped slaves. Angelou, in confirmation of Homi Bhabha's views on mimicry ${ }^{4}$ as "the most elusive and effective strategies of colonial power and knowledge" (Location 122 ) and a strategy of survival- "to keep the race alive", shows how the history of slavery can be written differently when conjured up and re-inscribed from a black perspective.

\section{(Derridean Hauntology...) Dr. Naglaa Saad M. Hassan}


Widening her spectral spectrum further, Angelou, using the same technique of overlapping voices and imagery, conjures up female specters in her poem "Our Grandmothers". In contrast to Western stereotypical images of stranded mindless women, the poet presents a highly positive portrait of a resilient empowering slave woman. In fact, the poem emphasizes Beaulieu's view that 'by focusing particularly on women who mothered under the conditions of slavery", re-inscribed slave narratives indicate that enslaved people "were not wretched but instead deliberate, determined and dignified" (XV). Just like the Derridean specters who repeat their visits, the poem is technically marked by a repetitive refrain - "I shall not be moved"- embedded in deftly knitted kinetic, visual and auditory imagery. Through smooth shift of spatial and temporal contours and the play on images of speech and movement, the poet ties female specters to a long history of women's suffering and fortitude. Hence, the poem starts by building an unidentified plantation setting at once appealing and repellent with the illusive joy-associated audible whispering and rustling leaves clashing with the repulsive and destructive images of "dirt" and hunting :

She lay, skin down in the moist dirt,

The canebrake rustling

With the whispers of leaves, and

Loud longing of hounds and

The ransack of hunters crackling the near

Branches. ( Collected Poems 253)

Though fettered, and muted, "she muttered, lifting her head a nod toward/Freedom". Through the typical overlapping voices technique denoting the inseparability of self and specter, we witness a quick shift from descriptive authorial narrative voice to the lyrical voice of the mother/specter who forcefully insists: "I shall not, I shall not be moved." As the long poem moves on, the

\section{(Derridean Hauntology...) Dr. Naglaa Saad M. Hassan}


spectral image gets gloomier and the woman's action gains momentum. We see her first gathering "her babies" whose "tears" are "as slick as oil on black faces" and whose eyes "convassing mornings of madness". As the craziness increases, the fettered act of "nodding" turns into hurried going and walking, the overlapping descriptive voices of the poet and mother turn into a dialogue between the mother and her sons:

Momma, is Master going to sell you

from us tomorrow?

Yes.

Unless you keep walking more

and talking less.

Yes.

Unless the keeper of our lives

releases me from all commandments.

Yes.

And your lives,

never mine to live,

will be executed upon the killing floor of

innocents.

Unless you match my heart and words, saying with me,

I shall not be moved. (Collected Poems 253 )

The breathless tone paralleled by the use of repetition, the free unrhymed verse and the short-sentenced lines reinforces the sharpness and zeal of the mother who is not only attempting to escape slavery but is also teaching her "babies" a lesson on the necessity of resistance in the quest for freedom.

In the succeeding stanzas the poet, assuming the authorial narrative voice, widens the spatial setting of slavery/freedom binarism, and by association slavery spectrality, by bringing into

\section{(Derridean Hauntology...) Dr. Naglaa Saad M. Hassan}


the scene various North and South slavery-inflicted cities and states. Hence, through an extended well-crafted panoramic image , we see " the complexity / in Virginia tobacco fields/leaning into the curve/ of Steinway...along Arkansas road/ in the red hills of Georgia" (Collected Poems 253 ) to finally fall "into the palms of her chained hands". In the midst of this manifold spatial setting, the voice of the protesting slave specter is heard reiterating: "You have tried to destroy me and though I perish daily, / I shall not be moved"(Collected Poems 253 ). Continuing to discredit the Eurocentric signifying hegemonic discourse, Angelou presents the slave as aware of all the stereotypical objectifying and derogatory names given to her in white history: "nigger, nigger bitch, heifer,/ mammy, property, creature, ape, baboon, /whore, hot tail, thing, it" (Collected Poems 254). Counterpoising such degrading signifiers is the woman's self-confident view of her "self":

my description cannot

fit your tongue, for

I have a certain way of being in this world, and I shall not, I shall not be moved (Collected Poems 254).

Through such forceful tone, the line between the slave/specter and the author is blurred with the effect of producing one fused intriguing identity defying atemporal oppressions. Such atemporality of prejudices is particularly substantiated by tailing the image of the slave woman being "bound" to her master's "bed" by that in which she is seen standing "before the abortion clinic" and " in the Welfare line/ reduced to the pity of handouts", such images which carry insinuations of recent triple oppression of women in the name of gender, race and class. Not only are black women suffering from sexual abuse and commodification because of their race and gender but they are also destined to endure abject economic conditions given their confinement to low classes. Notwithstanding the chain of 
unending racist prejudices, the slave specter, in full hegemonic agency, asserts that oppression "made her cry each time into a new voice", and reiterates : "yet, I must not be moved."

As the poem draws to a close, the poet, moving from the generic to the specific, discloses that such re-inscribed activist spectral figure is "Sheba the Sojourner", ${ }^{5}$ Harriet $^{6}$ and Zora ${ }^{7}, /$ Mary Bethune ${ }^{8}$ and Angela ${ }^{9}$ Annie ${ }^{10}$ to Zenobia", those female remarkable figures who-except for the black-coloured orientbased Zenobia ${ }^{11}$ - engraved their names in black American history, art and economy. The generic mother/specter branches out into a chain of historic heroines, only to shrink again to a single dominant specter, a "she", who remains in continuous quest for freedom. Accordingly, the poem ends with the symbolic slave/specter imaged as centering "the world's stage" and with the voices of the author and the slave still overlapping and inseparable, again to enhance the same existentialist Derridean perspective:

she sings to her loves and beloveds, to her foes and detractors:

However $I$ am perceived and deceived, however my ignorance and conceits, lay aside your fears that $I$ will be undone, for I shall not be moved (Collected Poems 254)

The foregoing high-pitched fervent tone- typical of Angelou's feminist empowering poems ${ }^{12}$ gives way to tranquil reflective notes in her short poem "Elegy" in which she conjures the specters of Harriet Tubman and Frederick Douglas and let them speak to their offspring in a singular reassuring voice:

I lie down in my grave and watch my children grow

Proud blooms above the weeds of death. (The Collected Poems 115)

(Derridean Hauntology...) Dr. Naglaa Saad M. Hassan 
The miserable children who "sprouted like young weeds" in the previous poem, and whom the mother/persona could not "shield their growth" are now imaged as "proud blooms" towering over weeds with "petals.. waving" and "seeds" falling and "press[ing] / beneath the earth" to form a non-ending relationship with the dead hero/heroine who declares: "my only need [is] to/fertilize their growth". Through such a floral extended metaphor, therefore, the poet succeeds in hammering home the persistent resistance of black people and in knitting the destiny of both the living and the dead and pinpointing the existentialist bond tying the black subject with his ancestral specters.

Still unable to resolve her existentialist dilemma nor to rid her agenda off the atrocities of White prejudice, Angelou, in her poem "We Saw Beyond Our Seeming" pictures slavery specters albeit in a defamiliarized way.

\author{
We saw beyond our seeming \\ These days of bloodied screaming \\ Of children dying bloated \\ Out where the lilies floated \\ Of men all noosed and dangling \\ Within the temples strangling \\ Our guilt grey fungus growing \\ We knew and lied our knowing \\ Deafened and unwilling \\ We aided in the killing \\ And now our souls lie broken \\ Dry tablets without token (Collected Poems 40).
}

Implicit here is the yoke of double oppression black people have endured in the name of race and class. The specters of children dying "bloated" implying hunger-caused death, and of men "noosed and "dangling" bring to mind torture images explored in 
previous poems. The use of the unidentified pluralistic firstperson voice, however, shows how Angelou engages all Americans, if not humanity at large, in the multi-faceted oppression targeting minorities in general and black people in particular. We are all held accountable. Angelou's message is that people's complacence maximizes hegemonic whiteness and its associated injustice. Using textuality, Angelou is conjuring the spectral atrocities of slavery to conjure it away. In existentialist terms, the poem indicates how the ontological self -questioning persona is seeking personal as well as communal integrity. Despite such attempts, the final image of the "broken souls" shows that the Hameltian dilemma of to be or not to be is still unresolved.

\section{Lucille Clifton, From Textual Specters to those of Mothers and Brothers}

why are the ghosts of the brothers and cousins wail rising and wailing toward me in their bloody voices, who are you, nigger woman, who are you? (Clifton Collected Poems 265)

The poetry of Lucille Clifton, a notable African American poet "of unusual talent and versatility" (Johnson 70) is fraught with textually-conjured haunting specters. Like Angelou's, Clifton's atemporally visiting specters are entangled with the question of being and hegemony. Uncrippled by gender and genre, Clifton's specters are sometimes masculine, as clear in the poem cited above, but can also be feminine, mythological and even textual. As is the case with Angelou, the specters of ancestors have overpowering presence and openly impose the existentialist Hamletian question: "who are you?". Although the poet is aware of her gender and colour ("nigger woman"), her subjectivity is still disrupted by spectral inheritances and memories. Clifton, "the seeker of vision", as goes the title of the 
poem quoted below, knows quite well the effect of spectrality on her Being and Becoming. Despite such certainty, she asks:

what does this mean

to see walking men

wrapped in the color of death,

to hear from their tongue

such difficult syllables?

are they the spirits

of our hope

or the pale ghosts of our future? (Collected Poems 453)

The specters of fathers and brothers are not only "walking men", but they are also, like Angelou's, speaking out: with their "bloody voices", they are "wailing", and from "their tongues", "difficult syllables" are bursting out.

Such ability to speak, with its suggestion of hegemonic agency is picked up in her poem "slaveships" which, informed by its title, conjures up scenes of slavery: ${ }^{13}$

Loaded like spoons

Into the belly of Jesus

Where we lay for weeks for months

In the sweat and stink

Of our own breathing

Jesus

why do you not protect us

chained to the heart of the Angel

where the prayers we never tell and hot and red

as our bloody ankles

Jesus

Angel

can these be men

who vomit us out from ships called Jesus

Angel

Grace of God

onto a m country

Jesus 


\author{
Angel \\ ever again \\ can this tongue speak \\ can these bones walk \\ Grace Of God \\ Can this sin live (The Collected Poems 503)
}

In her typical overflowing crisp punctuation-free style , Clifton lets her slave/specters pour out their unstoppable resentment and protest. Improvising as they are, they lay bare the falsity, deception and atrocities of white imperialism. The religious names- Jesus, angel, Grace of God- given to ships by imperialists show the oft-highlighted point of exploiting Christianity ${ }^{14}$ in manipulating slaves and colonized people. Clifton uses visual and olfactory images hand in hand with mundane domestic ones to hammer forth the inhuman treatment of slaves and to disrupt the false claimed holiness of imperialist mission. Hence, images of stinking, sweating, vomiting and the hot and bloody ankles. Notably, although the voices of slaves dominate the scene, towards the end of the poem, the fine line between their voices and that of the author is blurred with the ultimate result of merging both identities, much to the same Derridean existential effect. Such change to the authorial voice is marked by the change of linguistic register whereby mundane images give way to loftier ones. The maintained absence of punctuation marks, however, further enhances the fusion of voices.

In "Black Women" the persona is visited by the textual specter of Old Masse son, a fictional character created by Joel Chandler Harris in his collection Uncle Remus:

America made us heroines not wives, we learned the tricks to keep the race together but had to leave our men

\title{
(Derridean Hauntology...) Dr. Naglaa Saad M. Hassan
}


to find themselves

and now they damn

what they cannot forgive.

Even ol massas son

lives in a dream

remembering the lie

we made him love.

America made us heroines

not wives (The Collected Poems 503).

Though clad in New Critical ambiguity with some questions left unanswered about the type of "tricks", "heroines" and "lie", the poem strikes an unequivocal note about the communal suffering of African American "race", an idea which is linguistically enhanced by the use of the first-person plural voice throughout the poem. Despite vagueness, the unsaid sacrifices of both men and women to "keep the race together"- reminiscent of Angelou's image of keeping "the race alive", are pinned down. Unequivocal too is the visitation of the textual specter of Old Massa son that is inseparable from the ever-haunting "revenants" of slavery and imperialism. Focusing on the lives of black slaves in the postCivil War South, Uncle Remus features an ex-slave assuming the role of the narrator relating black slave history to the white grandson of his ex-master. Despite its significance in African American folklore tradition, the book raised much controversy given that its author was white. While some hold that the book's main theme is " the perpetuation of the stereotype of the "happy darky," a caricature created by white masters of the era to downplay the evils of slavery" ("Old Massa"), others, like Alice Walker, considers it a major encroachment on, if not theft of, Afro-American folklore tradition. With Clifton asserting that "Even ol massas son" / lives in a dream", and that the stories he was fed were lies, she is in fact grouping herself with the opponents of Uncle Remus and questioning the authorial

(Derridean Hauntology...) Dr. Naglaa Saad M. Hassan 
intentions behind the book. Clifton, as a writer and a black subject, is haunted by the textual African American symbols that were meant to shape American consciousness. That she is recovering from the effect the white textual specter exercised on her and proclaiming its falsity shows how she is re-possessing a new existentialist being. As a writer manipulating textuality, Clifton is, in fact, de-constructing the white-authored text and disrupting its authority. She is, to use Derrida's terms, conjuring the white specter to conjure it away. Clifton's black text is to neutralize the ever-haunting threatening white text; it is an attempt to cleanse the black consciousness from the false effect of the white-authored specter.

Notably, enhancing the Derridean state of revenant haunting specters, Clifton carries the words- "America made us heroines not wives" -of the unidentified voice in the previous poem into her poem "Conversation Overheard in a Graveyard" :

Harriet: This place has made us heroines not wives and kept us from its sparkles and its paints and made us dull in natural disguise. Sojourner: We've lost our ladyhood but saved our lives.

Harriet: What mirror will remember you and me suckling strangers and sons?

Sojourner: History (The Collected Poems 12)

The two speakers conversing in the poem can be the ghosts of two dead black Americans, or one alive- "Harriet"- and the other dead, the "Sojourner". If we take Harriet for a living persona and "sojourner" as one who resides in the grave, the conversation carries Hamletian overtones with Harriet seeking self-definition and reassurance through confrontation with the dead mother 
figure sojourning in the grave. If we take both for the specters of dead people, they will be the two abolitionist activists previously included in Angelou's poems. In both cases, the poem demonstrates the unending anti-black injustices and the difficulty of access into white-confined glamourous privileges symbolized in the above poem by the colourful light and paint. The image of "remember"ing in the final exclamatory question is suggestive of the ever-returning memories and the reference to "History", attests to the conscious role of textual conjuration in rewriting historical records.

A chief specter frequently met in Clifton's work is that of Kali, the Indian mythological goddess, worshipped in India , and embraced by feminists as a symbol of women empowerment. In three poems scattered along her Collected Poems, Clifton describes the nuances of the haunting experience showing how the spectral goddess is entangled with her quest for hegemonic agency and her troubled existentialist being. Notably, in Hindu mythology, Kali is said to have sprung "from the brow of the Great Goddess Durga, as a divine healing response to deal with the oppressive effects of unconscious masculine domination (Bashford 61). She is, therefore, a symbol of "a fierce, uncompromising, powerhouse of supreme feminine consciousness" (Bashford 61). In Clifton's three poems, we witness a persona aware of the power of the spectral goddess residing inside her and though attempting to subdue spectral authority, she is not in fact willing to exorcise her. A symbol of power, knowledge and healing, Kali is to be reconciled with the poet persona, and by association, with black femininity at large.

In " Kali", the reader gets to know how Kali , "queen of fatality" who "determines the destiny/ of things", is for black people like "nemesis" in Greek Mythology.

Kali

(Derridean Hauntology...) Dr. Naglaa Saad M. Hassan 
queen of fatality, she

determines the destiny

of things. nemesis.

the permanent guest

within ourselves.

woman of warfare,

of the chase, bitch

of blood sacrifice and death.

dread mother. the mystery

ever present in us and

outside us. the

terrible Hindu woman God

Kali.

who is black (The Collected Poems 152).

Notably, in imaging Kali , the poet trails the chain of negative diction - fatality, warfare, bitch, dread, terrible- with the final forceful affirmative statement "who is black". Such intensive, albeit unfavorable description is further foregrounded when set vis a vis the one-word fragment introducing white Greek goddess, "nemesis". In terms of quantitative stylistic elements, therefore, the hegemonic power of whiteness is offset by the black specter. Conforming to Derridean terms, the specter defies time itself since it is "permanent guest within ourselves" and "ever present in us" and is also inseparable from the self, an idea further augmented by the use of the proximal deictic prepositions "in" and "within". The state of haunting is communal; it is shared by black community and is meant to empower female blackness as clear in the manipulation of the use of first-person plural object pronouns - "us" , "ourselves."

In "the Coming of Kali", the poet depicts a state of haunting while further illustrating how the textually-conjured goddess informs the existential Being of the individual black subject here explicitly identified as female.

\section{(Derridean Hauntology...) Dr. Naglaa Saad M. Hassan}


It is the black God, Kali,

a woman God and terrible

with her skulls and breasts.

I am one side of your skin, she sings, softness is the other,

you know you know me well, she sings, you know you knowme well.

Running Kali off is hard.

She is persistent with her

Black terrible self. She

Knows places in my bones

i never sing about but

she knows $i$ know them well.

she knows.

she knows. (The Collected Poems 159)

Like Angelou, Clifton fuses the authorial and spectral voices. Despite such oneness, however, Kali assumes absolute power over the persona, a reading stylistically bolstered up by employing the lower-case first-person pronoun in describing the persona and the repetitive use of the verb "know" with its Foucauldian power/knowledge matrix overtones- in relation to Kali. The idea of power entangled with femininity- whether related to the mythological specter or the poet/persona- is particularly reinforced by the use of diction. Hence, the plural noun "breasts" with its associative "softness" is paralleled by the "skulls" and "hardness" with their cognitive insinuations. In Derridean terms, the specter of Kali is residing within the persona who, like Hamlet, is quite aware that the ghost is "persistent" and that "running" her "off" is hard.

In "Calming Kali", the haunted persona seems to have the upper hand, or to use Derrida's notions, she is able to reconcile 
her corporeal self with her non -corporeal specter, hence assuming hegemony .

\author{
be quiet awful woman, \\ lonely as hell, \\ and i will comfort you \\ when i can \\ and give you my bones \\ and my blood to feed on. \\ gently gently now \\ awful woman, \\ i know i am your sister (The Collected Poems 164)
}

Kali is still imposing her demands on the black complacent persona; she is still awful, "lonely as hell", and carnivorous, yet it is the persona who is "calming" her. Despite the use of the humble lower case of the pronoun "T", the authorial voice is loud and commanding. The "blood" and "bones" granted to Kali are foregrounded by their forceful alliterative stop consonants which show that the persona's corporeal self is not devoid of vigor. In contrast to the previous poem, the only verb of "knowing" is used in relation to the poet persona who is cognitively aware of the irrevocable kinship with the feminine goddess: "I know I am your sister".

Through the use of the mythological Kali figure, therefore, Clifton is able to write down the inner wavering workings of the black feminine self, deconstruct the Eurocentric stereotypes of feeble black femininity and re-inscribe black feminine power, valor and knowledge. Racher Harding rightly contends that "the images and language of the demands of the goddess parallel the unyielding of the orishas, lwas, and nkisis of the diaspora-forces of nature who equally guide and insist and who populate AfroLatin American religious traditions " (50). The care with which the poet/persona handles the specter's demands is in line with Derrida's concept that hauntology supersedes the ontology given

\footnotetext{
(Derridean Hauntology...) Dr. Naglaa Saad M. Hassan
} 
that the specter's existence informs the haunted subject's power, being and becoming.

In "Sorrow Song", Clifton, like Angelou in her poem "We Saw Beyond Our Seeming", widens the scope of her spectrology, conjuring the specters of all children victimized in the name of imperialist struggles:

for the eyes of the children,

the last to melt,

the last to vaporize,

for the lingering

eyes of the children, staring,

the eyes of the children of

Buchenwald,

of Vietnam and Johannesburg,

for the eyes of the children

of Nagasaki,

for the eyes of the children

of middle passage,

for Cherokee eyes, Ethiopian eyes,

Russian eyes, American eyes,

for all that remains of the children,

their eyes,

staring at us, amazed to see

the extraordinary evil in

ordinary men (The Collected Poems 263)

Clifton, in her oft-praised lucid register that frees itself from the confining limits of orthography and syntax, lets her words spill over the lines smoothly and freely. Her specters transcend the limits of race, space, language, class and gender. They are the universal ghosts of all victimized children whose lives were taken in the name of political hegemony. Following Derrida's theory, she is seeking justice, be it social, political or human per se . However, her specters are not conjured to be conjured away. They are meant to stay and re-visit us over and again to awaken human conscience as to the atrocities of political ambitions. Like

\section{(Derridean Hauntology...) Dr. Naglaa Saad M. Hassan}


Angelou's, Clifton's conjured specters are meant to remind the world of the communal global responsibility in homicides and brutal massacres. The specters are "staring at us"; we are all to blame. The feeling of guilt overwhelming Angelou's earlier-met speaker lies beneath the surface; the difference is that Clifton is fueling humanity's conscience; she engenders the sense of guilt in all of us, Eurocentric powers included.

\section{Conclusion}

The previous analysis of the two writers' selected poems has further solidified the fruits of advocating hauntology in fathoming the cultural, social and psychological dimension of African American poetry. Derridean theory of hauntology with its tripartite aspects- atemporality, hegemony and existentialist Being- as applied on Clifton and Angelou, helps illuminate the relationship between the nuances of individual and collective subjectivity on the one hand and the spectral legacies and memories on the other. It is our argument that Derrida's theory not only disrupts orthodox definitions of temporality given the specter's overwhelming control of present and future, but also deconstructs Derrida's theory of deconstruction with its proposition of the death of the author and the undeterminability of the text. Introducing the writer as a textual conjurer, Derrida reestablishes the authority of the writer over both the text and the audience and attributes to the text a pre-determined reading. Textuality and spectrality, therefore, entwine to enhance the role of creative writing in signification and re-signification and the inseparability of the self from its associative atemporal legacies and memories. The analysis of representative poems shows how Clifton and Angelou come close to each other in tackling specters of slavery in particular and oppression in general in their attempt to fathom the tensions working inside African American

\section{(Derridean Hauntology...) Dr. Naglaa Saad M. Hassan}


consciousness. In all the poems analyzed the black American subject confronts the historical spectral legacy of his community as well as his own personal revenants. In conjuring and confronting slavery specters - whether in the form of fathers, mothers, cousins, brothers or activists- both Angelou and Clifton are careful to dismantle Eurocentric discourse, empower black people and re-signify on historic legacies. Black slaves are reinscribed as heroic, brave, self-denying, witty and wise - images which disrupt Western monolithic narratives. In depicting subjective states of haunting, whether through human figures or mythological ones, the effect is to lay bare the tormented black American consciousness that is inseparable from chains of multifaceted forms of oppression with the ultimate goal of seeking reconciliation, self-definition and a stabilized answer to the Hamletian question of Being. 


\section{Notes}

${ }^{1}$ See Collin Davis, "Et At Present Hauntology, Spectres And Phantoms" for an analysis of the origin of Derrida's concept and the controversial ideas surrounding it.

2 A survey of pertinent scholarship on English and African American literature shows that Derrida's theory has been referred to in passing in numerous literary studies, and adopted as a critical background in a few ones. Primary amongst those studies is Katy Shaw's edited volume Hauntology: the Presence of the Past in Twenty-First Century English Literature in which Derrida's hauntology is adopted as a theoretical framework for the analysis of different forms of spectrality in selected British writings. Viviance Saleh -Hanna's "Black Feminist Hauntology" ties abolition to Derrida's theory in her reading of Toni Morrison's Beloved, a task repeated, though from a different angle, in Elisabeth M. Loevlie's article "Faith in the Ghosts of Literature: Poetic Hauntology in Derrida, Blanchot and Morrison's Beloved". There is no study, however, that attempted to probe Derrida's hauntology with its trinity of time, hegemony and being neither in African American poetry in general nor in the oeuvre of the two poets selected in particular. .

${ }^{3}$ Paul Escott argues that "probably no subject in American history has been mo re frequently researched " (177) than slavery

4 For Bhabha, mimicry is "a discourse constructed around ambivalence" and emerges in the conflict-ridden transactions between the colonizer and the colonized, particularly in the tension between the quest for stable identities required by colonialist rule and the counter pressure of rapid change and difference typical of colonial, and by association slavery- contexts. Bhabha underscores the role of mimicry in survival: "the effect of mimicry ", he maintains, "is camouflage ... It is not a question of harmonizing with the background, but against a mottled background, of becoming mottled - exactly like the technique of camouflage practiced in human warfare" (Location 85 ).

5 Sojourner Truth was an American abolitionist, known as the first black woman to win a case against a white enslaving master.

${ }^{6}$ Harriet Tubman (1822- 1913 ) the African American abolitionist renowned as the "black liberator." ( Women's history )

${ }^{7}$ Zora Neale Hurston is an African American writer associated with the Harlem Renaissance.

\section{(Derridean Hauntology...) Dr. Naglaa Saad M. Hassan


8 Mary Jane McLeod Bethune, the daughter of former slaves, was "one of the most important black educators, civil and women's rights leaders and government officials of the twentieth century"

${ }^{9}$ Angela is regarded as the first slave given a Christian name in historical records.

${ }^{10}$ Annie Turnbo, born to former slaves, was the first African American entrepreneur millionaire.

11 Zenobia was the queen of the Roman colony of Palmyra in Syria, from 268 to 272 AD. She conquered several of Rome's eastern provinces before she was subjugated by the emperor Aurelian Zenobia is described in many historical records as exquisitely black and attractive, which , besides her being a symbol of wavering scales of power and enslavement, might account for Angelou's fascination with her .

${ }^{12}$ See Angelou's much cited poems "Still I Rise", and "Phenomenal Women"

13 It is worth noting that Clifton's writing of slavery is informed by her own biographical background. As Rachel Elizabeth Harding writes " Clifton's great-greatgrandmother was an African woman, captured in Dahomey and enslaved in Louisiana, who, when still a child, walked from New Orleans to Virginia in a slave coffle “ (39)

${ }^{14}$ For a thorough analysis of the intricate relationship between white imperialism and Christianity see Khyat Y. Joshi's White Christian Privilege: The Illusion of Religious Equality in America. 


\section{Works Cited}

Angelou, Maya. The Complete Collected Poems. Random House, 1994.

Bashford, Sophie. You are a Goddess: Working with the Sacred Feminine to Awaken, Heal and Transform. Hay House UK , 2018.

Beaulieu, Elizabeth Ann. Black Women writers and the American Neo Slave Narrative : Femininity Unattended. Greenwood Press, 1999. Blanco, Maria del Pilar and Esther Peeren. The Spectralities Reader. Ghosts and Haunting in Contemporary Cultural Theory . Bloomsbury, 2013.

Bloom, Harold. May Angelou. Chelsea House Publishers, 2002.

Clifton, Lucille. The Collected Poems of Lucille Clifton 1965-2010. BOA Editions, Ltd, 2012.

Davis, Colin. "Hauntology, Spectres and Phantoms". French Studies, July 2005, 373-379, https://doi.org/10.1093/fs/kni143. Accessed 33 January 2020 .

Derrida, Jacques. Specters of Marx. Trans. Peggy Kamuf. Routledge, 1994.

Escott, Paul. D. Slavery Remembered. A Record of Twentieth Century Slave Narratives. University of North Carolina Press, 1979.

Fisher, Mark. "Specters of Accelerationism." In The Spectralities Reader. Ghosts and Haunting in Contemporary Cultural Theory. Bloomsbury, 2013. 
Harding, Rachel Elizabeth. "History, and Everyday Mysticism in the Poetry of Lucille Clifton: A Womanist View". Meridians , Vol. 12, No. 1 (2014), pp. 36-57.

Harriet Tubman. Woman History Museum.

https://www.womenshistory.org/education-

resources/biographies/harriet-tubman. Accessed 7 January 2020.

Johnson, Joyce. "The Limits of Celebration in Lucille Clifton's Poetry". Pacific Coast Philology, Nov., 1983, Vol. 18, No. 1/2 (Nov., 1983), pp. 70-76.

Joshi, Khyat Y. White Christian Privilege: The Illusion of Religious Equality in America. New York University, 2020.

Loevlie, Elisabeth M. "Faith in the Ghosts of Literature. Poetic Hauntology in Derrida, Blanchot and Morrison's Beloved", Religions, 4, July, 2013, pp. 336-350.

Luckhurst, Roger. 2002. "The Contemporary London Gothic and the Limits of the 'Spectral Turn." Textual Practice 16: 527-46.

Mary Jane McLeod Bethune. Woman's History.

https://www.womenshistory.org/education-

resources/biographies/mary-mcleod-bethune. Accessed 23 May 2019.

Miller, Nchamah. 'Hauntology and History in Jacques Derrida's Spectres of Marx."

https://www.nodo50.org/cubasigloXXI/taller/miller_100304.pdf.

O'Connor, Carrie. 'Reconstructing Eve Spectres and Identities of the Transforming Ideal". Double Dialogues, Isse 10, Summer 2009.

(Derridean Hauntology...) Dr. Naglaa Saad M. Hassan 


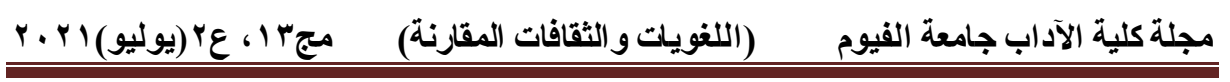

Saleh-Hanna, Vivane. "Black Feminist Hauntology Rememory the Ghosts of Abolition?" Champ pénal/Penal field, Vol. XII | 2015, 1-28. Sekora John. The Art of Slave Narrative: Original Essays in Criticism and Theory. Western Illinois University,1982.

“Uncle Remus". Encyclopedia

https://www.encyclopedia.com/children/academic-and-educationaljournals/uncle-remus. Accessed 21 July 2021.

Walla, Shelley. "Politics of 'hauntology" . Frontline. December 29, 2006.

https://frontline.thehindu.com/other/article30211905.ece. Accessed 24 January 2020.

(Derridean Hauntology...) Dr. Naglaa Saad M. Hassan 


\section{ملخص}

تتناول هذه الورقة جوانب من نظرية الهونتولوجيا عند الفيلسوف الفرنسي جاك دريدا تطبيقا علي مختارات من شعر الثاعرتين الافرو أمريكيتين مايا أنجلو ولوسيل كليفتون ، وتظهر الدراسة أهمية نظرية ديريدا عن الاطياف والاشباح في قراءة شعرهما كنموذج اللشعر الافروامريكي و تنقسم الدراسة قسمين : القسم

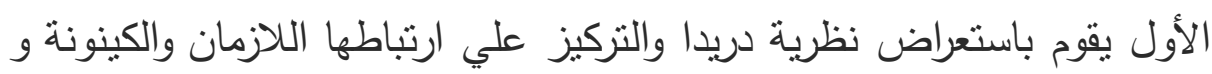
الهيمنة موضحا كيف أن الاطياف من منظور دريدا نسيطر علي الماضي دئي والحاضر والمستقبل و تحدد الوجود والصيرورة و ترتبط ارتباطا وثثيا بالسعي وراء الهيمنة الفعلية او الخطابية ـ اما القسم الثاني من الدراسة فيقوم بتطبيق النظرية بأبعادها الثناثة في قراءة لمختارات من شعر الثاعرتين ويساعد في تسليط الضوء على دور النص والمؤلف في الصراع على الهيمنة وفي محاولة التوفيق بين الاقطاب المتضاربة لوجوديته. ويظهر التحليل اشترالك الثاعرتين في ولي

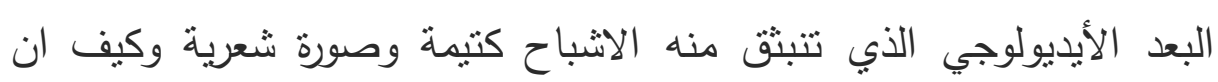
كلتاهما تشتخدمان النصية منتثلة في استحضار أثباح الاضطهاد بصورئه المختلفة في تفكيك خطاب سيادة البيض والقاء الضوء على الإرث الاستعماري المستبد للعنصر الأسود منذ أيام العبودية وحتي الوقت الحاضر. الكلمات المفتاحية: الهونتولوجيا ، جاك ديريدا، مايا اتجيلو، لوسيل كليفتون، الاطياف ، العبودية، الإرث الافرو الأمريكي 